I-Pop: International Journal of Indonesian Popular Culture and Communication

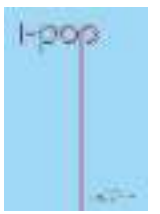

Vol. I (I) pp. 63-66, (2020) DOI: 10.36782/i-pop.vliI.I

\section{The Paradox about the Body in the Film "Imperfect"}

\author{
Muria Endah Sokowati ${ }^{*}$
}

\title{
ABSTRACT
}

Imperfect: Karir, Cinta dan Timbangan (2019), a film directed by Ernest Prakasa, is successful in reaching the box office, with an attracting audience of more than 2 million. This film is an adaptation of a novel with the same title written by Meira Anastasia and Ernest Prakasa.

Keywords

Body shaming, imperfection, washing practice, politics of representation, film studies

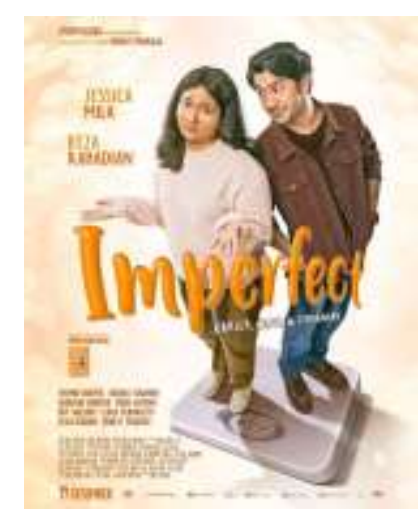

Director: Ernest Prakasa Writer: Ernest Prakasa, Meira Anastasia

Cast: Jessica Milla, Reza Rahardian, Dion Wiyoko, Karina Suwandi, Yasmin Napper, Boy William, Dewi Irawan

Producer: Chand Parwez Servia, Fiaz Servia

Distributor: Starvision

\section{INTRODUCTION}

This comedy-drama film focuses on the character of Rara (Jessica Milla), a target of body shaming because of her appearance, fat, and dark-skinned. In her family, her mother, Deby (Karina Suwandi), a former model often compares her to Lulu (Yasmin Napper), her younger, light-skinned sister. In the office where she works, her friends often underestimate her because of her appearance even though she is a smart employee. Rara has a boyfriend, Dika (Reza Rahadian), who loves her and doesn't care about her physical appearance. One day, there is an opportunity for Rara to get promotion in office, but her boss (Dion Wiyoko) requires her to change her appearance. Rara finally tried hard to lose weight, which then results in decreased health and conflict with her best friend, boyfriend, and sister. As a result, Rara decided to stop dieting and become herself again. At the end of the story, even though she gets fatback but with a more stylish appearance, Rara made it through all the conflicts and problems she faced. Her Relationship with Dika, her best

'Department of Communication Science, Universitas Muhammadiyah Yogyakarta, Indonesia

*Corresponding author: muriaendah@gmail.com 
friend, her family returned to harmony. The boss and coworkers, who had been bullying her, also successfully appreciated her work. Happy ending, imperfection successfully won.

Great narration led to many positive comments directed at this film. Some reviews in the media also stated that this film is both educative and entertaining. Just look at the review on Kompas.com (12/19/2019) titled Review Imperfect: Surat Cinta Bagi Mereka yang Dipandang Tak Sempurna (Imperfect Review: Love Letters for Those Who Viewed as Imperfect) (Sembiring, 2019). Or on IdnTimes (12/19/2019) with the title Review Film Imperfect: Penyampaian Pesan yang Mengena Melalui Komedi (Imperfect Film Review: Submitting Messages through Comedy) (Ahimsa, 2019).

Reading the positive reviews made me curious and wanted to watch this film too. Finally, watching the film Imperfect became our family activity at the end of the year in 2019. I agree with the reviews I read; this film is good, entertaining, and educational. This film touched me enough because many scenes in this film reminded me of my childhood and adolescence, which often became body-shaming targets from my family because of my dark skin, fat body, or my pug nose. All of that became an unpleasant past that makes me still feel insecure with my body.

But that is not what I want to share here. I am interested in writing something else about the film Imperfect that was quite annoying since the beginning of this film was talked about until I came out of the cinema.

\section{Why Jessica Milla?}

Since the beginning, I was not comfortable enough with the decision of the filmmaker to choose Jessica Milla to play the character of Rara in this film. Not because she is not good enough to act. In my opinion, Jessica Milla is too perfect for portraying Rara as an imperfect figure.

If this film aims to educate the audience to love the imperfections, then why the central figure is attached to a perfect image. I think everybody agrees that Jessica Milla is beautiful, Eurasian-faced, so that she must have light skin, slim body with long, straight hair. She has all the body elements that meet today's beauty standards.

But we know that Jessica Milla in that film has already transformed into a fat-bodied, with dark skin and curly hair? Yes, indeed, she has totality in acting. Praises are also addressed a lot to her.
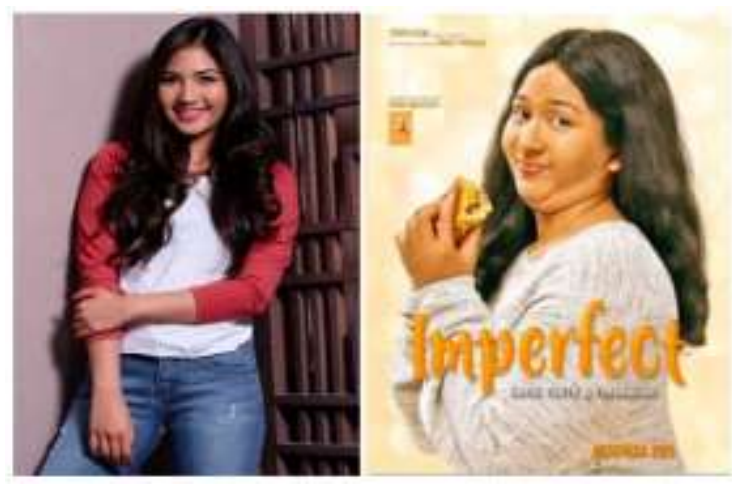

Figure I. Jessica Milla and Mira (source: Starvision)

It reminds me of Christian Bale, a Hollywood character who is willing to raise or lose extreme weight for the sake of role demands. Just check his filmography, such as The Machinist (2003) or The Fighter (2010), which makes him very, very thin, and Bale is suddenly fat in American Hustle (2013) or Vice (2018).

In this case, I appreciate Jessica Milla's effort. When realizing her story to increase her weight up to $10 \mathrm{~kg}$ instantly and then losing it again is an arduous struggle, because I often do the same thing. But, the difference is that I struggle to lose, not gain my weight.

That is the source of the annoyance that I mentioned earlier. Instead of demanding an artist to change her body shape, why don't the filmmaker cast a fat and dark skin actress? If it intends to educate about the appreciation of the body, this film finally has trapped again on the media-based beauty standard.

Ernest Prakasa and the production team were able to find alternative bodied figures for 
the complementary casts. They are Netty, a plump girl; Mary, a girl who always complains of her dark skin and curly hair; Endah, a shy girl with messy teeth; and Prita, who has a birthmark on her forehead. But, they didn't do the same way to cast Rara as the main cast.

The film viewer, like me, who smiles happily after watching the ending of this film, become insecure again when the TV show is performing Jessica Milla with her perfect body. Education is a long and ongoing process. It's not enough to watch one film, and then someone will change the mindset that has been embedded in them for a long time.

\section{The Practice of Washing in Film}

In film studies, we know the term whitewashing (Andrist, 2015; Tierney, 2017), which is the practice of casting in the film industry where white actors/actresses play non-white characters or ciswashing (Appenroth, 2015; Bagwell, 20I8), where transgender roles in films are represented by straight actors/actresses. Examples of whitewashing and ciswashing practices are when Jake Gyllenhall, an American actor, plays the character of Dastan in the film Prince of Persia: The Sands of Time (2010), or when Jared Letto plays the role of Rayon, a transgender person in the Dallas Buyers Club (20I3). In this film, Jared Letto successfully brought home an Oscar.

Both whitewashing and ciswashing become a big problem in Hollywood films because they have reduced the experience of minority groups to mere cosmetic makeup. The emergence of protests and petitions, making Hollywood now begins to change. During the film, Aladdin production (2019), Disney, as the producer, tried hard to find actors/actresses of Middle Eastern descent as the main cast. The result, as we know, it was a huge success. Disney also uses the strategy for film Mulan (2020). In this film, East Asian actors/actresses dominate.

Using the same logic, I see that the film Imperfect has also practiced washing, wash away the minority's bodily identity, in this case, women who have bodies outside the standards of beauty that apply in society. Washing practices in films are problematic in the politics of representation. We rarely find fat figures or dark-skinned positively portrayed in cinema. They become a mockery that is often cursed, treated harshly, and arbitrarily.

Indeed the film Imperfect narrates different things. It is the advantage of this film, which already represents the expression of the feeling of a woman whose body excludes the standard of beauty. But, it still has a problem since the representation of the woman's body in this film only at the cosmetic level, not the reality.

\section{Insecurity: the Problem of Imperfection}

I was intrigued to know why Ernest Prakasa and Meira Anastasia chose Jessica Milla as the cast of Rara. My search resulted in one interesting fact: the main reason for choosing Jessica Milla as Rara is because Jessica Milla is the only actress who is willing to change her body shape. This fact is quite disappointing to me. The choice of Jessica Milla was not due to the compatibility of Jessica Milla and Rara.

I came to think, is there no willingness for the production team to look for an actress to play a role as Rara who has a body like Rara? I think the mindset of the film industry does not support a figure like Rara to become an attraction for the success of the film.

In reality, fat women still don't get a decent place in the film industry in Indonesia. As a minority, fat women will always be treated as second-class women. How does it feel to be a second-class girl? Yes, the insecurity.

Try to see the headline on Liputan6, "Jessica Milla Terpengaruh Mentalnya di Film Terbaru" (Jessica Milla Mental Affected in the Latest Film). In that article (Sari, 2019), Jessica Milla said, "At that time, I rarely went out if it wasn't essential. If I have to leave, yes, I feel insecure. Even though people know that I'm in the shooting process for a film, but at that time, it affected my mentality. "

What does it mean? The actress who 
carries the educational mission feels insecure with her body that is not ideal. Is it just an ambiguity? If she becomes part of the team campaigning to the appreciation for the body, why she is not comfortable with her own body. That is the result of cosmetics; of course, the story is different if the actress playing a role as Rara has a body that is more or less the same. She will deliver messages about the body through the mindset of a person who experienced how to be a fat woman.

\section{Epilogue}

Too bad, it feels like a paradox. The film Imperfect has the potential to educate the audience about the body and the dangers of body shaming, but eventually, it just gets back to mere commercialization. Instead of changing the mindset, what is happening is precisely upholding today's beauty standards. If in the Hollywood industry, we know Ashley Graham, a plus-size model that appears to break down the beauty tradition, then it is time for our industry to give equal opportunities to fat women. I dream someday there is no sense of insecurity for overweight women. The film Imperfect should have been able to start.

\section{References}

Ahimsa, R. (2019, December 19). Review Film Imperfect: Penyampaian Pesan yang Mengena Melalui Komedi [Imperfect Film Review: Submitting Messages through Comedy]. IDNTimes.

https://jogja.idntimes.com/hype/entertainment/rij alu-ahimsa-I/review-film-imperfect-penyampaianpesan-yang-mengena-melalui-komedi

Andrist, L. (20I5, February 22). What is Whitewashing and why does it Matter? The Sociological Cinema. https://www.thesociologicalcinema.com/blog/wh at-is-whitewashing

Appenroth, M. N. (2015, September 27). The Ciswashing of the Stonewall Riots - Why Trans* Activists Can't be Heroes. Academia. https://www.academia.edu/ I624I72I/The_cisw ashing_of_the_Stonewall_Riots_Why_trans_a ctivists_can_t_be_heroes

Bagwell, M. (2018, July 14). Scarlett Johansson Responds to 'Ciswashing' Criticism After Being Cast as a Transgender Man in 'Rub And Tug'. Huffington Post. https://www.huffingtonpost.co.uk/entry/scarlet t-johansson-transgender-man-rub-and-tugcriticism-response_uk

Sembiring, I. G. N. (2019, December 19). Review Imperfect: Surat Cinta Bagi Mereka yang Dipandang Tak Sempurna [Imperfect Review: Love Letters for Those Who Viewed as Imperfect]. Kompas.com.

https://www.kompas.com/hype/read/2019/12/19/ I80500866/review-imperfect--surat-cinta-bagimereka-yang-dipandang-tak-sempurna?page=all

Sari, A. T. Y. (2019, November 10). Jessica Milla Terpengaruh Mentalnya Tampil Gemuk di Film Terbaru. [Jessica Milla Mental Affected in the Latest Film]. Liputan6. https://www.liputan6.com/showbiz/read/4I 06744 /jessica-mila-terpengaruh-mentalnya-tampilgemuk-di-filmterbaru?medium=Headline \&campaign=Headline click_I

Tierney, D. (2017, September II). From Breakfast at Tiffany's to Hellboy: The ongoing problem of Hollywood 'whitewashing'. Independent. https://www.independent.co.uk/artsentertainment/films/features/breakfast-at-tiffanyhellboy-hollywood-whitewashing-a793258I.html Vogel, J. (2018). The Confessions of Quentin Tarantino: Whitewashing Slave Rebellion in Django Unchained. The Journal of American Culture, 4 I (I), I7-27

\section{Notes on Authors}

Muria Endah Sokowati is a lecturer, researcher, and film enthusiast from the Department of Communication Science, Universitas Muhammadiyah Yogyakarta Indonesia. She pursued her PhD in Media and Cultural Studies from Universitas Gadjah Mada. Her main interests include communication and media studies, film studies, social media activities, and gender studies. This article is also published in Indonesian at Kumparan.com. E-mail: muriaendah@gmail.com. 